UDC $81-2$

DOI: $10.17223 / 24109266 / 6 / 5$

\title{
HISTORICAL AND CULTURAL DEFINING CHARACTERISTICS OF THE ENTRIES IN THE 1787 CENTURY DRAMA DICTIONARY
}

\author{
P.A. Zueva \\ Euroschool (Moscow, Russian Federation). \\ E-mail: euroschool@mail.ru
}

\begin{abstract}
This article deals with the results of socio-cultural analysis of the first theatre dictionary published in Russia in 1787 that has not been much studied in terms of interdisciplinary theatre arts criticism. The author looks at the 1787 dictionary as a historical and cultural product of a certain time period, discusses its social and cultural functions in the context of the evolutionary development of the Russian theatre, Russian dramaturgy and theatre life in the 18 th century.

Keywords: drama; theatre history; theatre arts criticism; the 18th century Russian culture; the Enlightenment; theatre studies; theatre evolutionary developments.
\end{abstract}

\section{Introduction}

In the 18th century theatre influence on Russian public life had greatly expanded, because, on the one hand, Russian amateur theatres blossomed out and, on the other hand, by 1756 Russia had been ready to develop its own national theatre and dramaturgy. The first play of the newly established Russian theatre, as noted in L.M. Starikova's work, took place on February 1, 1757 [1: 82]. The following periods are chronologically distinguished in the history of the Russian 18th century theatre:

- Theatre developments \& theatre life in Peter the Great's era [2-5];

- theatre and theatre life under Peter the Great's successors (Peter II and Anna Ivanovna [2, 4, 6] etc.);

- theatre and theatre life in the era of Empress Elizabeth Petrovna [6, 7];

- further theatre and dramaturgy developments during the reign of Catherine II $[6,8,9]$.

When considering the issues of theatre developments during the historic period under consideration, researchers often refer to different archival data, including rare and antiquarian books. The 1787 Drama Dictionary [10], is thought to be one of the most valuable materials in this respect for theatre arts analysis. This first theatre reference book appeared in the late 18th century, during the reign of Catherine II. And, although it did not escape the attention of some scholars $[5,6,11]$, its materials were mainly used either as a factual basis for literary discussion of 18th century playwrights' works, or when considering general issues of literature developments in 
the18th century, or for trying to solve some historical mysteries about the author of the 1787 Drama Dictionary because his identity appeared to have been unknown.

Even if the 1787 Dictionary was studied as a theater reference book by some researchers, it hadn't beenanalysed by them as a historical arts product of a particular historic time period. For example, M.V. Halizeva in her thesis research [5: 8-20], in one of its chapters, tries to describe some characteristics of the dictionary mentioned above, but in that description the author does not go beyond:

- some quantitative parameters (number of plays and pages, number of translated and original plays, foreign and Russian) without any attempt to interpret the factual information, proceeding from cultural and historical factors that influenced particular parameters of the edition under discussion;

- simple listing only of the most well-known foreign and Russian playwrights;

- some speculations about who might have been the author of the 1787 drama dictionary;

- some attempts to define - hypothetically, but very narrowly - the purpose of the 1787 Drama Dictionary: "Perhaps, the author was thinking primarily about the descendants, trying to preserve for them all the known facts of the then Russian theatre life..." [5:9], paying no attention to the Enlightenment spirit developing in Russia in the second half of the eighteenth century, especially during the reign of Catherine the Great, and, accordingly, an educational function of the dictionary under consideration and its refection in the structure and content of the 1787 Drama Dictionary.

In connection with what has been said above, it seems to be important in this article to give special attention to the structure and functions of the 1787 Drama Dictionary as a unique historical and cultural product of the end of the 18th century in terms of theatre arts criticism.

\section{Drama Dictionary}

\section{Analysis}

If we have a look at the title page of the 1787 Dictionary, we can easily notice that even its title tells us a lot about the author's purposes:

Drama Dictionary, or Alphabetic indications of all original and translated theater works staged in Russia, with the names of the aforesaid known authors, translators and composers, when these plays were presented in the theatres, and where, and at which time printed. In favor of loving submission of theatre. Moscow, 1787.

As can be seen from this rather long title, the author of the Drama Dictionary aims at sharing with the reader his knowledge on the theatre works 
staged in Russia and purposefully selected by him for his dictionary entries. $\mathrm{He}$ also finds it important to inform the reader which of the theatre works were original plays (and in case of foreign plays, the country of their origin and their language) and which of them were plays translated into Russian. Accordingly he differentiates between playwrights as authors and translators as cowriters. Besides, the author of the dictionary finds it possible to use the word "composers", hinting at the possible presence of music in this or that play.

In the title of the considered Drama Dictionary the author also promises to inform the reader about when and where (in which theater) plays were staged, and even when and where they were printed. And if the information about the time and place where a particular play was staged had mostly a factual value, then the information about the time of its publication could have mostly commercial and educational values. This is indirectly confirmed by the analysis of 19th century landowners' library catalogs, for example, the library catalog of the Bryanchaninovs, Vologda noble family [12], which includes a majority of plays described in the 1787 Drama Dictionary. Sometimes the Dictionary title - "Drama Dictionary" - may be wrongly interpreted by a modern reader, unless he or she refers to the very content of entries, which includes plays associated with the broader meaning of the term "drama", because not only dramas referring to a genre were included in the author's dictionary entries such as comedies and tragedies and some dramas as specific plays, but operas, ballets, mystery plays and history-bound theatrical performances devoted to the most important events in the Russian history.

The 1787 Drama Dictionary is an alphabetical catalog-like list of entries on foreign and Russian plays (339 plays), which have been selected by the author with the author's introduction and some additional comments on some plays in the dictionary text. As further seen from the title page, this dictionary has been purposefully and primarily designed for theater lovers and by one of its lovers. This is reported in the author's introductory article and what is of no less interest is that the author emphasizes that he is not a writer, but he has done this work mostly for all kids and young people interested in theatre as a form of educational entertainment. Still the author hasn't hesitated to publish it, believing that he has done a good deed (esteeming a favor for the public) [10: A4].

\section{The cultural circumstances of the appearance}

However, in order to understand more deeply for whom this dictionary was created, it is necessary to refer to some cultural and historical events that took place in the 18th century, such as:

1. 1740 was marked by building up an extensive network of amateur (including school and student) theatres in Saint-Petersburg, Moscow, Kazan, Novgorod, Tver and other cities, that completely lost their original church connection. 
2. Democratic population circles took wide initiatives in staging home theatrical performances.

3. The first state regulation of theatre life in Russia found its expression in 1750 in the publication of the first legislative act of Elizabeth Petrovna's theatre that gave official permission to put on performances with "Russian comedies" in private houses, providing, however, that "no religious or other habit related to spiritual people should be worn, and not to walk or ride the streets in such and other similar dresses used for performing on comedies" [13].

In the introductory article to the Drama Dictionary, the author pays special attention to the Enlightenment role of theatre. The author is safe to say that "The whole enlightened world knows well how useful and also funny are theater plays that lead not only to well-behaved child-rearing; pleasant sermons without memory burdening during spare time bring fun and pleasant amusement to an older person; when educating infants, theatre works encourage kids' good behavior, clearly revealing the severity of vices, temptation to weaknesses or predilection for credulity, impudence, suspicious shyness, disobedience and many other human faults and weaknesses" (emphasized by P.A. Zueva) [10: A2].

The author's introduction traces a clear tendency of using theatre as an instrument of Enlightenment, characteristic of the latter half of the 18th century. In other words, at that time theatre had got a new task - to release the human mind from old prejudices and introduce new, enlightened life ideas and true morality. So, the 18th century theatre became not only a place for entertainment, but also a school of reason and morality [14]. Talking about the Enlightenment, one should remember that a number of various dictionaries appeared in Russia together with the 1787 Drama Dictionary, such as "Alphabetical register of Russian products, natural and handmade" by M.V. Lomonosov, "Lexicon..." by V.N. Tatishchev, etc. [15], because they were much needed by the Russian educated community and, in particular, its elite for making progress in different areas of human activity.

Thus, theatre as a form of leisure is opposed to some other forms of pastime activities, characteristic of Russia's past: "Who will praise the joy of past centuries? They fought with beasts and with each other until death, considering it to be heroic; fistfights were the best entertainment show, parents brought their children there to be amused; and how to make it possible that in childhood a person wouldn't open his heart to bitterness and violence; until recently even noble women were spectators of this disgrace" [10: A3]. The author believes that with the advent of the Enlightenment era, new opportunities to use theatre as an instrument of promoting Enlightenment ideas in Russia, including provincial theatres, not only theatres located in Saint Petersburg and Moscow. In his introduction the author draws the reader's attention to the fact that "Fortunately our aforesaid time has changed; the 
Enlightenment triumphs, good behavior and tenderness are manners; cruelty disappears, violent amusements are left everywhere, no ignorance can be seen even in the remote Russian provinces..." [10: A3-A4]. In this passage, the author focuses on some important changes in Russian society values and morals. The author specifically emphasizes that "Everyone knows that in ten-year time and less chiefs, which manage Russian cities remote from the capital, thought up with the then nobility to start honorable and useful amusements; we hear about theatres, which were built and are still built that have quite decent actors. Noble people much to their amusement and general use try to write and translate theater works; it is noticeable that children of noble people and even commoners admire theatrical performance more, than persecution of pigeons, horse hunting or hare baiting, and reason about plays. I myself was a witness of this in provinces" [Ibid: A4]. In addition to what has been said, it is also interesting to pay attention to the fact that the 18 th century theatre as a form of entertainment doesn't serve only nobility, because its public range extends and commoners became an inseparable part of theater-goers.

\section{The 1787 dictionary structure and content}

The 1787 Drama Dictionary describes different types of theatre works including primarily tragedies and comedies, and also some dramatic works, comic operas, ballets and musical performances staged in the 18th century Russia. Only after having read the dictionary entries, the reader begins to understand the true meaning of the 1787 Drama Dictionary title. In terms of terminology, the Dictionary title uses the first meaning of the "drama" - any theatrical work. Most plays, listed in the considered dictionary, belong to different varieties of comedies (67.7\% of the total number of plays), or tragedies (16.7\%).

However, it should be noted that in the author's description of plays some of them are called "drama", for example, when describing the "The Triumph of Love" play: "THE TRIUMPH OF LOVE. A drama in three acts written in Russian by Vasiliy Levshin, published in Moscow by N. Novikov's University Press in 1787 [10: 142]. In this case, the "drama" term is used to refer to serious plays with no heroic content (unlike comedy and tragedy) of middle class people life: "Drama... means any kind of theatrical act; therefore, sad comedies refer neither to true comedy, nor to tragedy in its general meaning" [16:251].

Though the structure of the dictionary entries varies, still it is quite possible to identify some common pieces of information included in the descriptions of theatre works there. Among them are as follows:

- naming the title of any theatre work and its genre;

- indicating whether it is a translation (and from what language) or actually a Russian original play; 
- indicating a play authorship (though sometimes the author's name is given only as an acronym), including the author's name, surname, rank and title, if s / he has the latter) and including as well sometimes the translator's name;

- giving information about the printing house, where each of the plays was printed;

- publication year.

For example, "HAMLET. A tragedy by Alexander Sumarokov, that is an imitation of Shakespeare's play, English writer, presented for the first time in early 1750s at the Imperial Theatre in St. Petersburg, printed in Moscow at N. Novikov's University Press in 1781" [10:35].

Variable components of dictionary entries may include additional information about:

1) the direction of a particular theatre work and audience's opinions and reflections on it;

2) characteristic features of the translation of this or that play;

3) the names of famous actors or actresses involved in acting;

4) moral and ethical values of a particular theatre work;

5) emotive and expressive information (though rather seldom).

For example, most of Voltaire's works are characterized as the best examples of French playwriting: "ZAIRE. A tragedy of Voltaire considered the best of French drama works..." [Ibid: 59] or "ALZIRA. A tragedy in five acts, Voltaire's famous play, was staged in Russian by somedrama amateurs. The enlightened world knows that this tragedy is the greatest work of the writer..." [Ibid: 16].

When analyzing the dictionary entries on plays produced by Russian playwrights, it is easy to notice that much praise is given to A. Sumarokov's tragedies, it is vividly seen in the follwoing: "SINAV AND TRUVOR. Sumarokov's tragedy in five acts. ...There is no need to describe the importance of this famous tragedy, hoping that everyone interested in theatre plays highly respect it..." [Ibid: 127] and "SEMIRA. A tragedy of A. Sumarokov... The beauty of verses and heroic characters are worthy of respect and immortality of the author. This tragedy was translated into different European languages and was printed many times. Lately Sumarokov's workshad been collected and printed in Moscow at N. Novikov's University Press in 1781" [Ibid: 124].

In the dictionary under discussion the author introduces many plays written by the most prominent Russian and foreign playwrights of the 18th century, though one can also come across a few works written by less known authors. Among foreign playwrights one can find in the dictionary wellknown works by Moliere, Voltaire, Racine, Corneille, Lessing, Goldoni, Destouches, Marivaux, Regnard, Marmontel, Terentiusand a number of oth- 
er less known authors. Many of these plays were translated from French, German, Italian Latin and even Polish.

Newly-born Russian dramaturgy of the period under discussion is represented in the 1787 Drama Dictionary with works of A.P. Sumarokov in the lead and plays of A.O. Ablesimov, M.I. Verevkin, A.A. Volkov, Ya.B. Knyazhnin, V.P. Kolychev, D.P. Korchakov, M.V. Lomonosov, V.A. Levshin, V.I. Lukin, V.I. Maykov, N.P. Nikolev, M.M. Kheraskov, D.I. Fonvizin (although compared with other playwrights, he is represented only by one play - "The Minor"). However, not only were the plays by prominent Russian and foreign playwright listed and described in the 1787 Drama Dictionary. The reader may also come across some information on amateur translators of foreign plays and even playwrights who were great theatre lovers and for whom these activities were a kind of a noble hobby. In other words, this dictionary gives us a unique information on writing plays as a part of leisure, a peculiar hobby of the nobility of those times and not only a professional occupation. Among these amateur authors there army officers and even generals (for example, "Virtue crowned with faithfulness" of M.I. Prokudin-Gorsky), actors (for example, I. Sokolova's plays), and young ladies and gentlemen from nobility circles.

It should also be added that according to the opinion of the dictionary compiler, the role of a translator of foreign plays has been as important, as a playwright's job. That was why he provides in his dictionary besides the names of playwrights, the names of translators in most cases as well. Moreover, the description can contain not only their names, but also additional information, such as their social status, their belonging to a particular social stratum/ social class. Many of them later became famous Russian playwrights like M.I. Verevkin. Thanks to the 1787 Drama Dictionary we learn that translations were made by amateur translators, among them pupils of the Cadet Corps and the Institute of Noble Maidens, students of Moscow State University, actors themselves, military men of that time, family members of landowners and others.

It is interesting to note that in addition to the Western European theatre works that are described in the considered dictionary, references to Eastern European theatre works are given some attention to. In quantitative terms, the number of foreign plays staged in the 18th century Russia greatly predominates over Russian plays (the number of foreign plays comes to 55\% of all plays listed and described in the dictionary foreign plays, meanwhile the number of Russian plays is equal to $37 \%$, the plays without the author's identification are up to $42 \%$ ). This can be explained, on the one hand, by a huge European influence, which was and in some way encouraged by the Russian rulers of that time, and, on the other hand, by the process of developing Russian theatre public conscience and, accordingly, Russian playwriting. Russian dramaturgy is a part and parcel of broader achievements in the 
18th century literature. And what is worth mentioning in this connection are the following: Cantemir's satires, Trediakovsky's contribution to the reform of Russian verse, Lomonosov's contribution to the further development of the Russian poetic language, Trediakovsky's, Lomonosov's and Sumarokov's dispute on the most arguable questions of drama theory and practice.

As has been said earlier, the Drama Dictionary was already published in 1787, but it was certainly compiled much, much earlier. And this should be taken into consideration when analyzing the terminological content of this dictionary as a cultural source of evolutionary theatre developments in Russia in the indicated period.

\section{Conclusion}

To conclude, it should be said that the preliminary analysis of the structure and content of dictionary entries in the Drama Dictionary of 1787, let us assume that it can be widely used for research purposes as one of the most valuable documentary sources that helps to create a more specific and detailed picture of theatre developments in the context of Enlightenment ideas that were spread in Russian society in the second half of the 18th century. And to understand in particular, to which extent the changes in Russian theatre life, dramatic creativity in Russia and have changed the public vision of theatre as a valuable cultural experience and stimulator of translating foreign plays into Russian that sometimes even bring to life Russian-history-andcustoms-bound versions of foreign plays and getting involved in writing national plays.

\footnotetext{
${ }^{1}$ In 1749 , the servant Kondraty Baykulov submitted an application to the Moscow police with a request to allow him to "play comedies". At the same time in Moscow a group of enthusiasts, led by bureaucrats Hilkovsky and Glushkov, submitted a similar request. In 1755, "a solicitor, Kazan seminary student, trained and moved from Slavonic-Greek-Latin Sciences, Ivan Varfolomeev, Nordinsky son" organized a troupe. The copyist Kochergin, plumber Stepanov, "Ink masterof Moscow Printing House" Ivanov and many others submitted applications regarding public performances. In a word, theatre attracts great attention of "wide" artisans [14: 59-60].
}

\section{References}

1. Starikova, L.M. (1997) Theatre in the XVIII century Russia: Experience in documentary research. Moscow: State Institute of Art Studies, A.A. Bakhrushin State Central Theater Museum. $152 \mathrm{p}$.

2. Varneke, B.V. (1908) History of the Russian Theatre. Part One: XVII and XVIII centuries. Kazan: Typolithography of the Imperial University. 360 p.

3. Ignatova, S.S. (1914) Theatre of Peter's Time. History of the Russian Theatre. V.V. Kalash, N.E. Efros (eds.). 1. Moscow: Book Publishing "Obyedineniye”. pp. 69-88. 
4. Stennik, Yu.V. (1974) Playwriting of Peter's time and the first Sumarokov's tragedies: (To the statement of the question). Problems of literary development in Russia in the first quarter of the XVIII century. Leningrad: Nauka. pp. 227-249. (XVIII cen. Col. 9).

5. Halizeva, M.V. (2001) Russian theatre reference books and their makers. Art History Cand. Diss. Moscow. 138 p.

6. Arapov, P.A. (1861) Chronicle of the Russian Theatre. Saint-Petersburg: N. Tiblen and Comp. Printing House. 368 p.

7. Brodsky, L.N. (1914) Theatre in the era of Elizabeth Petrovna. History of the Russian Theatre. V.V. Kalash, N.E. Efros (eds.). 1. Moscow: Book Publishing "Obyedineniye". pp. 103-134.

8. Evstratov, A.G. (2009) Catherine and the Russian Court Playwriting in 1769 - early 1770. Philology Cand. Diss. Moscow. 296 p.

9. Varneke, B.V. (1914) Theatre during the reign of Catherine II / History of the Russian Theatre. V.V. Kalash, N.E. Efros (eds.). 1. Moscow: Book Publishing "Obyedineniye". pp. 115-210.

10. (1787) Drama Dictionary, or Alphabetic indications of all Russian theater essays and translations, with the names of the aforesaid known authors, translators and composers that when they were presented in the theatres, and where, and at which time printed. Moscow: A.A. Annenkov Printing House. 166 p.

11. Berkov, P.N. (1959) "Drama Dictionary" of 1787. From the history of Russian literary relations of the XVIII-XX centuries. Moscow; Leningrad. pp. 52-65.

12. Morozov, P.O. (1889) History of the Russian Theatre until the half of the XVIII century. Saint-Petersburg: Publishing House: SPb. V. Demakova Printing House. 446 p.

13. Shambinago, S.K. (1914) Theatre of the time of Peter II and Anna Ivanovna. History of the Russian Theatre. V.V. Kalash, N.E. Efros (eds.). 1. Moscow: Book Publishing "Obyedineniye". pp. 89-107.

14. Danilov, S.S. (1944) History of the Russian Drama Theatre. Moscow: Zvezda. 612 p.

15. Vompersky, V.P. (1986) Dictionaries of the XVIII century. Moscow: Nauka. 137 p.

16. (1984-1991) Dictionary of the Russian Language of the XVIII Century. The Academy of Sciences of the USSR. Russian Language Institute; ed. by U.S. Sorokin. Leningrad: Nauka, Leningrad branch. [Online]. Available from: http://feb-web.ru/feb/s118/slov-abc. 